\title{
Orofacial Injuries in Eclamptic Nigerians
}

\author{
KCNdukwe , VI Ugboko, IO Ogunlola, ${ }^{2}$ EO Orji ${ }^{2}$ and ONMakinde ${ }^{2}$
}

\begin{abstract}
A retrospective review of one hundred and seventy three cases of eclampsia seen between 1994 and 2002 was conducted. Twenty one patients $(12.1 \%)$ whose ages ranged from 18 to 35 years sustained orofacial injuries during the course of their eclamptic fits. Lacerations and bruises on the tongue, gingivae and lips accounted for injuries in all the patients. Temporomandibular joint dislocation was also recorded in one patient. Tongue lacerations were mainly due to tongue biting. Forceful insertion of objects during convulsive episodes was responsible for the bruises and deep lacerations at the ventral surface of the tongue in two patients. Two patients died from severe and uncontrolled bleeding complicated by renal failure and aspiration pneumonia from lacerations on the tongue and gingivae. Vigorous campaign should be carried out to encourage antenatal care attendance by pregnant mothers so that potential cases of eclampsia could be nipped in the bud before progressing to frank eclampsia. Furthermore, additional injuries usually inflicted on pregnant women by anxious relatives from forceful insertion of unpadded objects as mouth props should be discouraged through public health promotional campaigns. Obstetricians should be aware of the possibility of these injuries in an unconscious eclamptic patient and their life-threatening consequences if not promptly diagnosed and managed. The need to seek appropriate and early dental or maxillofacial consultation where such injuries are suspected and where services are available is imperative. (AfrJ ReprodHealth 2004; 8[3]:147-151)
\end{abstract}

\section{RÉSUMÉ}

Les blessures buccofaciales chez les Nigérianes éclamptiques. Une analyse rétrospective de cent soixante-treize cas d'éclampsie traités entre 1994 et 2002 a été faite. Vingt-et-un patientes (12,1\%) dont l'âge variaient entre 18 et 38 ans ont eu des blessures buccofaciales au cours de leurs crises éclamptiques. Des dilacérations et des contusions sur la langue, sur les gencives et sur les lèvres étaient responsables des blessures chez toutes les patientes. La luxation de l'articulation temporo-mandibulaire a été notée chez une patiente. La dilacération de la langue a été largement occasionnée par la morsure de la langue. L'insertion par la force des objets pendant les crises convulsives était responsable des conditions et des dilacérations profondes à la face antérieure de la langue chez deux patientes. Deux patientes étaient mortes à cause de l'hémorragie qui n'a pas été maîtrisée et qui a été compliquée par l'insuffisance rénale et la pneumonie de déglutition provoquée par des dilacérations sur la langue et les gencives. Il faut des campagnes rigoureuses pour encourager la fréquentation à des consultations pré-natales par les femmes enceintes pour que les cas d'éclampsie soient écrasés dans l'œuf avant que cela n'avance vers l'éclampsie pure. De plus, il faut décourager les blessures supplémentaires infligées aux femmes enceintes par des parents anxieux qui font entrer de force des objets non-outinés dans la bouche comme des soutiens à travers des campagnes de la promotion de la santé publique. Il faut que les obstétriciens soient conscients de la possibilité de ces blessures chez la patiente éclamptique inconsciente et leurs conséquences extrêmement graves si elles ne sont pas diagnostiquées et traitées. Il est impératif d'avoir recours aux consultations dentales ou maxillo-faciales où les blessures sont traitées et où les services sont disponibles. (Rev Afr Santé Reprod2004; 8[3]:147-151)

KEY WORDS: Orofacial injuries, eclampsia, Nigerians

${ }^{1}$ Departments of Oral and Maxillofacial Surgery; and ${ }^{2}$ Obstetrics and Gynaecology, College of Health Sciences, Obafemi Awolowo University, Ile-Ife, Nigeria

Correspondence: Dr K. C. Ndukwe, Faculty of Dentistry, Obafemi Awolowo University, Ile-Ife, Nigeria. E-mail: kizitondukwe@yahoo.com 


\section{Introduction}

Eclampsia refers to seizure activity or coma unrelated to other cerebral conditions in an obstetrical patient with pre-eclampsia., While most cases present in the third trimester of pregnancy or within the first 48 hours following delivery, rare cases have been reported prior to 20 weeks gestation or as late as 23 days postpartum. ${ }^{1}$

The incidence of eclampsia varies from one part of the world to the other and is increased in women of low socio-economic status, extremes of age and primigravid state. Approximately $5 \%$ of pregnancies in the United States are complicated by preeclampsia. Of these patients, $0.52 \%$ progress to frank eclampsia. ${ }^{1,3}$ Studies conducted in Nigeria show comparable incidence figures with other developing countries but is much higher than those quoted for the industrialised nations. ${ }^{3-6}$ This has been attributed, amongst other factors, to lack of antenatal and intrapartum care for the teeming obstetric population.

Pre-eclampsia/eclampsia affects women within the reproductive age group and the aetiology is unknown. Both pre-eclampsia and eclampsia account for significant maternal and fetal morbidity and mortality. They account for approximately 50,000 maternal deaths worldwide annually ${ }^{1,3,6}$ However, in the developed countries the maternal mortality rate from eclampsia has been reduced with early diagnosis and aggressive management, and is currently less than $1 \%$. Maternal complications of eclampsia may include permanent central nervous system damage from recurrent seizures or intracranial bleeds, renal insufficiency and death. In addition, seizureinduced complications include tongue biting, head trauma, fracture dislocations or aspiration. $^{7-10}$

A review of literature shows that there are sparse reports on the incidence and pattern of maxillofacial injuries in eclamptic women following seizure episodes. The present study aims at documenting the prevalence and pattern amongst Nigerians attending a tertiary health care facility. To our knowledge none of such reports exists in the English literature.

\section{Patients and Methods}

One hundred and seventy three patients who presented with eclampsia at the Department of Obstetrics and Gynaecology Obafemi Awolowo University Teaching Hospital, IleIfe, Nigeria from January 1994 to July 2002 were retrospectively reviewed. In this study, eclampsia was defined as the occurrence of convulsions during pregnancy or within the first ten days postpartum, in conjunction with at least two of the following features recorded within 24 hours of the convulsion: hypertension (a diastolic blood pressure of at least $90 \mathrm{mmHg}$ ), proteinuria (at least $2+$ protein in random urine sample or $-1.0 \mathrm{gm}$ of protein in 24 hours collection) or thrombocytopaenia (platelets count of less than $100 \times 10^{9} /$ litre).

Information retrieved included patients' demographic characteristics, antenatal history, parity, location and type of facial injury, mechanism of injury, associated injuries, treatment given, complications and outcome.

The data were expressed as means and percentages. 


\section{Results}

One hundred and seventy three cases of eclampsia were diagnosed within the study period. Of these, 21 patients (12.1\%), whose ages ranged from 18 - 35 years (mean \pm SD; $26.1 \pm 6.0$ years), sustained orofacial injuries during the course of their eclamptic fits. Twelve of them were primigravida while nine were paragravida. Of the 21 cases, 19 (90.5\%) were unbooked for antenatal care prior to presentation in the hospital.

Table 1 shows the type of injuries sustained and their location. In general, the injuries were mainly limited to the orofacial soft tissues with lacerations and bruises accounting for injuries in ten and eight patients respectively. The tongue recorded the highest number of lacerations (10 cases), while most of the bruises were seen on the lips (six cases) and gingivae (two cases). Temporomandibular joint dislocation was recorded in one patient.

The lacerations on the tongue were mainly due to tongue biting except for the forceful insertion of unpadded objects' like spoons or spatulas (wooden and metallic) during convulsive episodes, which was responsible for the bruises and deep lacerations at the ventral surface of the tongue in two patients. The single case of temporomandibular joint dislocation recorded in the present study occurred during one of these manoeuvres.

With regards to treatment, most patients had antiseptic dressing of the orofacial wounds. However, antibiotics were prescribed in all the cases as part of the treatment regimen for eclampsia. Dental or maxillofacial referrals were sought in only two cases.

Two deaths $(9.1 \%)$ were recorded in the study; one had severe bleeding from deep lacerations on the ventral surface of the tongue. This patient was taken to a general practitioner where she was transfused with six units of whole blood and the lacerations were sutured before referral to the teaching hospital. Subsequently, oozing from the sutured laceration continued and a maxillofacial consult was sort by the attending obstetrician. However, the patient eventually died from acute renal failure and septicaemia. The second patient suffered deep lacerations in a similar location but this was only discovered while attempting to intubate for emergency caesarean section. Severe and uncontrolled bleeding ensued in both cases, which was complicated by acute renal failure and aspiration pneumonia.

\section{Discussion}

\section{Table 1 Injuries Sustained and their Locations in 21 Patients}

\begin{tabular}{ll}
\hline Type of injury & Location (number of patients) \\
\hline Bruises & Lips (6) \\
& Gingiva (2) \\
Lacerations & Tongue only (8) \\
& Lips/tongue (2) \\
$\begin{array}{l}\text { Bruises/lacerations } \\
\text { patient) } \\
\text { Joint dislocation }\end{array}$ & Lips/tongue (3) \\
\end{tabular}

\footnotetext{
* Some patients sustained more than one injury
} 
Eclampsia continues to be a prominent cause of maternal and perinatal morbidity and mortality particularly in the developing countries of the world. ${ }^{1-6}$ The most frequent of these morbid complications are acute renal failure, hyperpyrexia and aspiration pneumonia. ${ }^{3-5}$ Others include wound sepsis, post-caesarean section and urinary tract infections. ${ }^{4}$ Some authors have even documented fracture dislocations of the manubriosternal and hip joints respectively. ${ }^{7-}$ ${ }^{11}$ The present study recorded the prevalence of orofacial injuries (12.6\%), ranging from lip biting, tongue lacerations to temporomandibular joint dislocation amongst these group of patients.

Orofacial injuries arising from seizurerelated disorders are well-recognised. ${ }^{12}$ They range from soft tissue bruises of perioral and intraoral structures especially the lips, gingivae and tongue to facial bone fractures. The soft tissues, especially the tongue and lips, could be traumatised from biting as a result of the vigorous jaw movement that usually accompanies fitting episodes or from direct trauma from the teeth in the event of these tissues being trapped between the jaws when the patient falls down. Fractures of the facial skeleton arise from direct effect of falls following sudden loss of consciousness. Parade ground or guard's man fracture of the mandible is a well-documented feature of epileptic attack, where the patient falls right with the chin to the ground while standing erect, fracturing the chin as well as both condylar necks of the mandible. ${ }^{12}$ Saah et $\mathrm{al}^{7}$ also reported a rare case of tongue-biting complicated by macroglossia, causing respiratory obstruction in an eclamptic patient. In the present study, tongue-biting, as well as insertion of unpadded objects as mouth props, were responsible for the lacerations recorded. Although the ensuing macroglossia that accompanied injury to the tongue was not severe enough to cause respiratory obstruction in our series, the resultant massive bleeding probably worsened the prognosis in two patients whose tongues were pierced by unpadded objects.

Eclamptic patients have pregnancyinduced persistently elevated blood pressure that may progress to hypertensive encephalopathy with its accompanying seizures. ${ }^{13}$ The occurrence of orofacial injuries like lip or tongue lacerations either from biting or insertion of objects in the mouth predisposes the patient to acute, severe and uncontrollable haemorrhagic episodes that may possibly cause renal failure and aspiration pneumonia especially in the unconscious state. The resultant effect will be a worsened prognosis and possibly death. This is exemplified by the mortalities recorded in the present report.

Although the patients were both primi and multigravids, it is instructive that majority $(90.5 \%)$ of them were unbooked for antenatal care prior to presentation in hospital. Perhaps these cases may not have progressed to eclampsia if the patients had attended antenatal clinics. Hence, the nonattendance of antenatal checks may partly account for the high prevalence of orofacial injuries amongst the study population, coupled with the insertion of unpadded objects as mouth props.

In our locality, therefore, a vigorous campaign should be stepped up to encourage antenatal care attendance by pregnant mothers so that potential cases of eclampsia could be nipped in the bud before they 
progress to frank eclampsia. Furthermore, additional injuries usually inflicted on this category of patients by anxious relatives from forceful insertion of unpadded objects as mouth props should be discouraged through public health promotional campaigns at antenatal clinics and in the community. It is also pertinent for obstetricians to be aware of the possibility of the presence of these injuries in an unconscious eclamptic patient and their life-threatening consequences if not promptly diagnosed and managed. The need to seek appropriate and early dental or maxillofacial consultation where such injuries are suspected and where services are available is imperative.

\section{REFERENCES}

1. Duley L. Maternal mortality associated w it h hypertensive disorders of pregnancy in Africa, A sia, Latin America and the 53. Caribbean. BrJ Obstet Gynaecol 1992;99: 547 -

2. Castro LC. Hypertensive disorders of pregnancy. In: Hacker N and Moore JG (Eds.). Essentials of Obstetrics and Gynecology. 3rd edition. Philadelphia: WB Saunders Inc, 1998, 196-207.

3. Saftlas AF, Olson DR and Franks AL: Epidemiology of preeclampsia and eclampsia in the United States, 19791986. Am J Obstet Gynecol 1990; 163: 460-465.

4. Dare FO, Eniola OA and Bariweni AC. Eclampsia revisited. NigJMed 1998; 7: 168-171.

5. Odum CU. Eclampsia: an analysis of 845 cases treated in the Lagos State University Teaching Hospital, Nigeria over a twenty year period. Cen AfrJMed 1991; 9: 16-19.
6. Douglas KA and Redman CWG. Eclampsia in the United Kingdom. Br Med J 1994; 309: 13951399.

7. Saah D, Braverman I, Elidan J and Nageris B. Traumatic macroglossia. Ann Otorbinol 1993; 102: 729-730.

8. Varma AN, Seth SK and Verma M. Simultaneous bilateral central dislocation of the hip an unusual complication of eclampsia. J Trauma 1981;21:499-500.

9. Browne AO and Sheehan JM. Bilateral central dislocation of the hip: a case report. Orthop Rev 1986; 15: 733-135.

10. Dastgeer GM and Mikolich DJ. Fracturedislocation of manubriosternal joint: an unusual complication of seizures. J Trauma 1987; 27: 9193.

11. Moller B and Lindmark G. Eclampsia in Sweden, 19761980. Acta Obst Gynaecol Scand 1986; 65: 307-314.

12. Aragon CE, Burneo JG and Helman J. Occult maxillofacial trauma in epilepsy. J Contemp Dent Pract 2001; 4:26-32.

13. Rivers EP. Preeclampsia, eclampsia, and other hypertensive disorders of pregnancy. In: The Clinical Practice of Emergency Medicine. 2nd edition. 1996,315-21. 